In their 1979 manifesto, the independent experimental theatre collective Kugla glumište (Zagreb, 1975-1985) claims: "Kugla discovers images, symbols and stories that wish to be the promise of community." The article explores the repercussions of those neo-avantgarde community efforts on the contemporary Zagreb non-institutional scene by analysing four inclusive performances which differ in motivations, aesthetic aims, production levels and participatory modes. In The Love Case of Fahrija P (2017), the ex-members of Kugla and additional co-authors stage a polylogue with the artistic heritage of the deceased Kugla glumište member Željko Zorica Šiš (1957-2013) and the inclusive procedures they devised during the 1970s. The community project 55+ (2012) by the production platform Montažstroj gathers the participants who are over 55 in workshops, public debates, celebrations, protests and a documentary to provide visibility and voice to that neglected generation. In the trilogy On Community (2010-2011), the production platform Shadow Casters tests different mechanisms of creating temporary aesthetic communities, from learning an a cappella group song to sharing secrets, on its recipients. Finally, the atmospheric inclusion of the subtly associative performance Conversing (2019) by Fourhanded offers an almost elitist opportunity of co-existing in the intimate world of private tensions. However, what they all have in common is a physically non-invasive form, emotional and/or intellectual engagement and an emphasised personal commitment that can oblige audiences to reciprocate while they join the community of experience.

Keywords: Zagreb non-institutional theatre of the 2010s, community of participants, On Community, 55+, The Love Case of Fahrija P, Conversing

Višnja Kačić Rogošić is an assistant professor at the University of Zagreb, a member of the editorial board of the Croatian Theatre Journal and an associate of the Miroslav Krleža Institute of Lexicography, She published the book Group Devised Theatre (2017). She was a Fulbright Fellowship Program scholar in 2010/2011 (CUNY, New York City, USA). She is a member of the Croatian Centre ITI and is on the executive committee of the Croatian Association of Theatre Critics and Theatre Scholars.

vrogosic@ffzg.hr 


\title{
Keeping the Promise of Community: Communal Efforts on the Contemporary Zagreb Non-Institutional Scene
}

\author{
Višnja Kačić Rogošić \\ University of Zagreb, Faculty of Humanities and Social Sciences
}

The Zagreb non-institutional theatre scene provides elements of communal experience (reflected in the creative process, performance or reception) both in the obscure and well-known theatre practice, in memories and archives, in retrospective interpretations and the straightforward strategic activities as well as in various periods of its recent history. Although one can find under investigated examples of the theatrical exploration of this field in the first part of the $20^{\text {th }}$ century, ${ }^{1}$ it particularly developed amid the 1970 s' rediscovery of collective power on the alternative scene, when even groups with clearly individualised creative tasks avoided naming specific authors (community of performers/authors) and interaction with the audience was almost expected (community of participants), and was perhaps most elaborately realised in the practice of the neo-avant-garde experimental theatre group Kugla glumište (1975-1985). In the words of their 1979 manifesto: "Kugla discovers images, symbols and stories that wish to be the promise of community" (79). ${ }^{2}$ The following paper will attempt to chart

\footnotetext{
1 For instance, in the summer of 1940, the members of the theatre company Družina mladih (1939-1948), which was founded within the French Institute in Zagreb, undertook a methodological experiment containing some of the recognisable elements of community building such as physical isolation and connecting through a consciously chosen common creative process. As remembered by the surrealist writer and the influential group member Radovan Ivšić, "(e)nough young people warmed up to the practice, so we decided to spend the summer together in the village of Razvor, on the river Sutla, and dedicate all that time to making theatre. It was in Razvor that Družina mladih set up its chorus for choral recitations, which was one of group's basic activities for years, along with the acting and the puppetry" (156). Thus a barely registered practical research overflowed into the formal innovation implying a strong collective base, both on the organisational and performative level. Choral performance was suggested by Ivšić who also provided powerful modernist choral recitations such as Sun City (1943-1944) as linguistic texts of their performances. Diverging from the desirable and generally accepted realistic conversational style it recalled ritual heritage of the theatre performance and musical quality of the stage speech, according to the description of the composer Ivo Malec: "We did choral recitation as a sort of musical-vocal piece. We spoke the text in such a way that the word or the sentence would shift from one mouth to the other creating a certain musical surrounding" (161).

2 Kugla's claim reverberated across various layers of the group's existence. It was tested in the organisation of the group as its members experimented with "creating their working surrounding as a primary social group" (Burić quoted in Marjanić and Vlašić-Anić 48). It was transferred to the creative process which, regardless of the informal domination of more experienced and more charismatic members and in spite of sometimes slow-moving progress, relied primarily on the group discussion and nominal equality in making decisions. It was manifested in the performance marked by the fragmented dramaturgy (a sequence or a cluster of separated scenes) resulting from the artistic polylogue and a group body of performers united in a procession or a tableau vivant. Finally, it was dispersed by the invitation to the spectators to join their participative projects, as clarified by the group: "The problem is that so far Kugla's success has been evaluated according to AESTHETIC and not social criteria [...] no one has ever noticed that this is a different kind of social activity" (Mor 86).
} 
contemporary repercussions of that communal legacy on the same independent theatre scene by analysing four projects from the 2010s: On Community (O zajedništvu, Shadow Casters, 2010-2011), 55+ (Montažstroj, 2012), The Love Case of Fahrija P (Ljubavni slučaj Fahrije P, group of authors, 2017) and Conversing (Razgovaranje, Fourhanded, 2019). Namely, with different motivations, aesthetic goals, production levels and modus operandi, they do not necessarily refer to the term but do focus on a group of interconnected individuals united by means of cohesion, particularly in relation to the audience. Thus, the analysis will especially explore the interactive and participatory potential of each of the performances employed to form a social organisation, exploring the political potential of the community or its practical and ideological background. If there is a common starting point, it can be found in their positive perception of the community, whether it is proposed as a probable outcome, a question or "wishful thinking". As Zygmunt Bauman observes, somewhat ironically, "Community, we feel, is always a good thing" (1).

\section{A possible community}

The positive side of the spectrum is marked by the belief in the successful establishment of performative unity of all those involved in a theatre performance. Up to a certain point, it is a natural outcome of the $20^{\text {th }}$-century experiments in that field that completed the cycle from devising fresh models to their practical testing, from envisioning ideals to accepting attainable versions, from subverting conventions to inaugurating new conventions and even joining the mainstream. Some form of communal theatrical experience is thus nearly presumed or at least less problematised and exceeds the presented material or serves as its denominator - obtained like a previously existing pattern and applied with a lot of optimism or acceptance of its shortcomings to the new circumstances. Accordingly, the theatre performance The Love Case of Fahrija $P$ (Theatre \&TD, opening night: 13 December 2017) directly links to that neo-avantgarde heritage. It was created by a group of authors, ${ }^{3}$ including Zlatko Burić Kićo and Damir Bartol Indoš, who once belonged to Kugla glumište; even more so, upon the disintegration of the group in the early 1980s, they respectively represented its "soft" and "hard" fractions. In addition, the project is a homage to another deceased Kugla member and multimedia artist, Željko Zorica Šiš (1957-2013), and therefore rendered in the form of performative dialogue with his artwork; in particular, it is based on three comic pages from 1984 (The Love Case of Fahrija P, Mummies, Ed Killer Hed) with references to his other works such as partially edible installations, the experimental film Cabbage Clairvoyant (2012) or the reflections of his fictional alter-

3 Zlatko Burić Kićo, Damir Bartol Indoš, Dragana Milutinović, Tanja Vrvilo, Hrvojka Begović, Dina Puhovski, Sven Jakir, Domagoj Janković, Miro Manojlović, Ivan Marušić Klif, Igor Hofbauer Hof, Henning Frimann Larsen, Peter Oliver Jørgensen and Ana Janjatović Zorica. 
ego Dr Hans Christian Zabludovsky published in two fantasy bestiaries. It does not, therefore, come as a surprise that the project relates to Kugla's opus on the level of content, dramaturgy, spatial organisation and highlighted media. Zorica's motifs are incorporated into the mixture of everyday scenes and surreal fiction, which the group established in the mid-1970s juxtaposing, for example, the spectacular multimedia staging of the crime story about Fahrija P. with a simple, realistic tale about ordinary people, a peasant family growing cabbages.

Furthermore, the production is shaped in four spatially and thematically separated segments, of which some are additionally divided into mutually independent parts: postdramatic interpretation of Zorica's comic plots staged on two more conventional scenes is followed by a succession of performances on small scaffold stages representing various loci and a musical finale in an empty hall. Along with acting, it features music - a possible nod to the famous Kugla band, which accompanied all of their shows - and a strong visuality, interweaving live acting and drawing, film, installation and projections of comics, a debt to the multimedia oeuvre of Željko Zorica.

Most importantly, within the context of this insight, The Love Case of Fahrija P continues to rely on its audience, leaving the impression of a collection of procedures designed to persuade the spectators to renounce that status in favour of physically active or more conscious participation. On the general level, the fragmentary disposition of particular scenes is surpassed by a collective processional body of audience members led by one or more performers from one performance locus to another. The invitation to join it is issued calmly ("Let us go! Let us move!" announces the actor Sven Jakir after the introductory scene. "Go, now, follow the snowstorm into the hall and take a look at our other images" encourages the actress Tanja Vrvilo after the end of Fahrija's story). Still, it cannot hide the implicit ultimatum: join the group or miss the performance altogether. On the level of particular segments, the authors interlace different channels and intensity of inclusion. By directly addressing the viewers demanding their alert intellectual engagement and openly showing or presenting the performance content, for example, in the central sequence on scaffold stages, they practise the Brechtian abolishment of the fourth wall convention to create a firm connection between the stage fiction and the reality of the auditorium. To quote the official announcement: "Come to the show, in the words of Ed Killer Hed, to see - when you are already watching." At the same time, all the segments appeal to the sensory experience of the recipient with the ever-present musical performance, which alternates in force with acted parts, occasionally transforming a theatre piece into a concert. The Love Case of Fahrija $P$ begins with forceful tones (composed and performed by Miro Manojlović, Henning Frimann and Peter Ole Jørgensen and enriched with the operatic voice of Dina Puhovski), continues with a dynamic background of our experience and finishes with a full-blown acoustic environment which envelopes everybody. 


\section{A questionable community}

If the neo-avant-garde theatrical investigation of community highlighted its potential in the creation of a theatre performance (and vice versa), it has also contributed to the precaution with which some contemporary theatre-makers return to that concept. One bears in mind the difficulties in maintaining the popular neo-avantgarde model of the community of equals and many theatre collectives that dispersed under the pressure of the uncomfortable tension between common values and individual freedoms. Thus, on an abstract level, certain positive insecurity or even amusing scepticism can be applied to the very idea of community, for example, concerning the motives and possibilities of its realisation as well as sustainability. However, when tackled with curiosity and/or critically, the community cannot avoid becoming one of the thematic or formal problems of the project. Such reserved and questioning attitude is demonstrated by the production platform Shadow Casters (2001-) which opened the 2010 decade with the performance trilogy On Community 4 (2010-2011) "examining the community and communal experience through multiple reasons for their establishment, energy and socio-political conditions and changes" (Shadow Casters Explicit). In the opening part, Explicit Contents ${ }^{5}$ (Zagreb Youth Theatre, opening night: 9 May 2010), presented in the form of six interlaced audience journeys through the theatre building, each led by a pair of actors, the authors focus on creating the "arranged community". The second performance [R]evolution Master Class $^{6}$ (Belgrade, Atelje 212, opening night: 14 September 2010) - again a group psychophysical interaction between the audience and the performers, although mostly in a single joint space - instigates the re-evaluation of the community through its "decomposition and reestablishment", while the finale Male/Female - Female/ Male $^{7}$ (Theatre \&TD, opening night: 25 February 2011) divides its "basic energies male and female" only to confront them in "the laboratory-theatrical dialogue" (Ibid.). Regardless of the formal variations, all the performances share several specificities important for the main topic of this article. First of all, the community that Shadow Casters question is a theatre community: with the exception of a few fragments, ${ }^{8}$ it is placed in the spatial and temporal context of a theatre performance (although it can occur in the working rather than the performance spaces within a theatre building) and is limited to the participants of a theatrical event. Throughout the

4 Concept: Boris Bakal; direction: Boris Bakal and Katarina Pejović.

5 Dramaturgy: Boris Bakal, Katarina Pejović, Stanko Juzbašić; co-authors and performers: Lana Barić, Goran Bogdan, Lada Bonacci, Ivana Buljan Legati, Nikša Butijer, Edvin Liverić, Vilim Matula, Maro Martinović, Nadja Perišić Nola, Barbara Prpić, Urša Raukar, Vedran Živolić.

6 Dramaturgy: Boris Bakal and Katarina Pejović; co-authors and performers: Aleksandra Janković, Hristina Popović, Ana Marković, Joana Knežević, Srđan Jovanović, Bojan Krivokapić.

7 Dramaturgy: Vedrana Klepica, Stanko Juzbašić, Dražen Novak; orchestrator: Stanko Juzbašić; co-authors and performers: Irma Alimanović, Benjamin Bajramović, Boris Bakal, Nikša Butijer, Dean Krivačić, Zrinka Kušević, Vili Matula, Jelena Miholjević, Mona Muratović, Petra Težak (Boris Ler).

8 In Explicit Contents one group of the audience is shortly led outside of a theatre building blindfolded while in [R]evolution: Master Class one of the groups leaves the theatre to go write graffiti on city walls. 
particular segments, the authors thematise various contemporary group identities such as family, nation, gender, a circle of acquaintances or intimate friends, or even a dance group, generally relating their experiment to the wider social circumstances. However, they eschew a firm connection with any specific examples or models of community, thus preserving a more neutral character of the problem. Furthermore, the described "laboratory" conditions allow for the fully inclusive nature of the trilogy, which strives to invite the recipients into all or most of the phases of the complete project. They attend the Opening Night, a symbolical starting point of the devising process, not to witness the performance but to join the discursive search for common interests upon which the performance would be built. They are invited to support the creative process as the necessary "rehearsal audience" because "without the participating audience, there is really no performance" [R]evolution and are eventually, using various mechanisms, placed into the very centre of the artwork. Namely, the development of each of the performances in great part consists of gathering the audience into one or several smaller or larger groups to lead them through some performative tasks: share a secret with your partner, learn a group dance/an a capella song, take a collective bow, meditate on flying, give an opinion, enter a conversation, etc. Following the authors' conviction that the evolution of the individual is the precondition for forming a sustainable community, the tasks tend to have a more or less emphasised emancipatory character. The outcome is doubly rewarding. On the one side, it enables the performers to "catch up" with the audience who are conventionally more experienced in their recipient roles than the actors are in whichever role they embody (Explicit Contents 2010). Thus, they balance out the general inequality of the temporary theatrical community. At the same time, it tests one's decision to become and/or remain a member of that same body by examining its particular qualities: the vulnerability or protection of the individual within a group, features with which a group might identify, the way it chooses to present itself, or treat the non-members. Finally, if Shadow Casters are comprehensive when setting up an experiment, they are equally open when it is time to provide the results since the trilogy progresses towards more focused problems rather than clear solutions. Although the tendency is visible in all its parts, it is perhaps most evidently presented in the last one, which is constructed as four different performances in the form of elaborate group discussions: a performance by male performers intended respectively for male and female spectators and a performance by female performers intended respectively for female and male spectators. Namely, in each of the four variants, a group of gender equalised spectators is welcomed by a group of gender equalised performers in the hall, where the seating is symbolically placed in concentric circles. The audience is then invited to an informal two-hour long socialising session with occasional, subtly offered, "provocative" discussion issues or activities which might unite/divide present communities, considering their specific gender profile 
(for example, "Would you agree that this is a man's world and that men should be blamed for everything wrong in it?" or "What would be an acceptable way to end a relationship?"). Male/Female - Female/Male thus lucidly suggests: whether the circumstances for creating any community are favourable or not, its realisation remains the matter of our individual responsibility.

\section{A wanted community}

The same "problem-based" approach is perhaps most appealing in relation to a specific community - one that is achievable, existing or even desirable, just not unconditionally. Therefore, starting from a more concrete communal experience (or a lack of one), many artists strive to discover its optimal or at least more functional version as well as the road to its actualisation. As their name suggests and their manifesto statement confirms, the Artistic Organisation for Opening New Fields of Theatre Communication Fourhanded is strongly preoccupied with this sphere of research. Specifically, the organisation is dedicated to the "realisation of refined communication" and "always wants to gather a group of participants" only to anchor them to their immediate surrounding with the socially engaged performance, one that Fourhanded defines as "co-acting, co-dealing with what is around us" (Četveroruka manifestno). Even more so, the meticulous examination of means and ways to achieve performative community serves as a distinguishing methodological feature of their work: "We are interested in dealing with the materiality of the connections established by the theatrical event between its participants and in shaping that materiality [...] with the consciousness that every form is the result of the joint investment made by the subjectivities of both audience and performers" (Ibid.). Those interests serve as the premise of the fourth episode in their artistic-exploratory cycle Distances, ${ }^{9}$ which is inspired by the crisis of interpersonal relationships caused by the Croatian War of Independence (1991-1995). The series of performances was initiated by the theatre director Marina Petković Liker in 2017 with the investigation of the postwar conditions in the small Baranja municipality of Darda (East Slavonia). ${ }^{10}$ The authors used an economically and socially devastated and politically, nationally and humanly deeply divided place as the paradigmatic example of insurmountable barriers in communication in contemporary Croatian society. ${ }^{11}$ Hence their performance

\footnotetext{
9 The whole cycle is comprised of the following episodes: Distance - Focusing (2017); Distance - Falling behind (2017); Distance - Point 285 (2018); Neither Friend nor Brother (2018) and Conversing (2019).

10 Initially, the research also included Maja Sviben (dramaturgy), Eva Kraljević (camera), Miro Manojlović (editing), Luka Gamulin (sound) and Nina Đurđević (camera).

11 In relation to the project, the authors describe "one of the elementary problems of the current moment" as "lack of understanding and fear from the other as well as aggressive and destructive impulses towards the other and oneself" "Udaljenosti - fokusiranje".
} 
significantly named Conversing ${ }^{12}$ (2019) chooses both thematic and methodological approach to the subject, which is additionally elaborated by the juxtaposition of the documentary material - audio recordings of the conversations between the authors and women from Darda, and its theatricalised reflection. Thematically, the recorded conversations establish the outline of the "distances", i.e., the ambivalence between the necessity and the impossibility of overcoming described social crisis and continuing promising co-existence. At the same time, Fourhanded employs the "authenticity" of the media to affect the performers and the audience. Expectedly rendered in a discursive format, the performative reaction to this problem is presented by six female performers who attempt to maintain a functional conversation. One of the key characteristics of their approximately two-hour interaction is the difficulty with which a series of monologues fuses into a polylogue and the easiness with which the participants of that polylogue misinterpret each other or take opposing sides. And although that "jazz discussion"13 (live group improvisation with several performance tasks in relation to the living material) does not provide a clear story, characters or even time and space, the distance between women symbolically gathered around one table and trapped in a vicious circle of miscommunication is transparent. If the change is possible, it seems that it can be instigated by the recipients (gathered in an equally symbolic way in a wider circle around the performers) who Fourhanded recruits as "witnesses". Namely, as the precondition for the understanding and unity which is out of reach of performers, the authors encourage the audience to develop analytical insight, accept conscious co-existence and feel responsibility but also warmth: they juxtapose different perspectives, they share the space and do not ignore the spectators, they personalise invitations to the performance and blur its temporal frame by inviting audience members to join them in an informal conversation over drinks afterwards. They hope that "after you've spent an hour or two noticing something in a different way, it will continue to vibrate even when you leave" (Petković Liker quoted in Kačić Rogošić).

As opposed to the subtle intervention into everyday life conducted by Fourhanded, the performance group and production platform Montažstroj advances with much more urgency and force. In addition, their project with the suggestive title $55+(2012)$ is the only one among those presented in this text (regardless of their more or less evident social function or the legacy of the same kind), which is categorised as community theatre with a more direct utilisation and a clear goal. That status of applied theatre project provides a better understanding of its key features, as recognised by Kees Epskamp, "the exchange of the ideas between the participants and leaders/actors", the connection between the content of the performance and "the life surrounding of the

12 Dramaturgy: Maja Sviben; sound design: Luka Gamulin; performers: Lada Bonacci, Slavica Jukić, Jasna Palić Picukarić, Barbara Prpić, Urša Raukar, Dijana Vidušin.

13 The term is used by the director Marina Petković Liker as one of the experimental elements of her methodology. 
participating community", problematisation of issues which are "of direct importance for the community where the performance or the workshop are happening" and encouragement of the audience "to directly participate in the event during or after the performance" (Lukić 22-23). Therefore, the comprehensive enterprise targeted at the population aged 55 years and over thematises the position of that population in contemporary Croatian society. According to the author of the concept and theatre director Borut Šeparović, the members of that age group are considered less potent and rendered "invisible". Therefore, the multiphase project is designed to call attention to their forgotten potential. To enable the circulation of ideas that will result in the performance 55+ - Years Are (Not) Important ${ }^{14}$ (Vatroslav Lisinski Concert Hall, opening night: 23 September) and a documentary film Consumed ${ }^{15}$ (2014), the project starts with the week-long interviews with the possible future participants and continues with workshops for the 99 invited non-professional performers. Divided into four media categories (theatre, movement, new-media and group discussion), they aim at activating the participants and providing them with new skills while at the same time fusing the individual members into a "micro-community". Interaction with the audience, however, is tackled in different ways with varying success. On the one side, a long final theatre performance "provides a voice" for each of its 44 performers by giving them the opportunity to present the most important minute in their lives as well as give an engaging speech on current social problems, intended for the audience. However, as noted by the theatre scholar Una Bauer, our ethical responsibility to hear and react to those voices is significantly weakened by the representational frame of the theatre, which transforms soul-stirring reality into a dramaturgically monotonous line of approximately one-minute long confessions followed by an equal number of mostly uninventive speeches by non-professional speakers (2012). On the other side, the two-month-long joint preparations for the grand finale succeeded in creating an agedetermined community of project participants who, for example, initiate additional socially-engaged activities or offer suggestions for their manifesto ("Vremeplov"). Since 55+ is not presented as a one-time endeavour but is offered as a "model-project", which can be transferred to another context with different participants (Šeparović 77), it opens a parallel channel for the dispersion of communal experience. In the words of Šeparović: "I believe that art has great potential when it is created in strong correlation with the transformation of the local community. If we want to consider the power of political theatre at all, it has to take from the community and give back to the community" (76).

14 Dramaturgy and transcript adaptation: Nataša Mihoci, Borut Šeparović, Jasna Žmak; performers: Miljenka Androić Marić, Jadranka Barlović, Miran Cencić, Renata Dossi, Mira Egić, Zvonimir Fritz, Marijan Frković, Josip Grosek, Mira Inkret, Branko Ječmenjak, Barbara Juraja, Ante Kaštelan, Lidija Kleščić, Ana Knežević, Marica Komljenović, Nada Kos Balen, Zlata Lešković, Blaženka Levak, Marija Lovinčić, Gordana Lovrić, Jasna Paravina, Stanka Pavuna, Nada Pejša, Emil Pernar, Eduard Pešun, Ljudmila Peterfai, Božidar Petrina, Miljenko Pinterić, Višnja Pleško, Žarko Potočnjak, Ljubica Radmanović, Vlasta Ritting, Hermina Rukavina, Franciska Šimenić, Vladimir Šimenić, Slavko Šoić, Miro Šola, Dražen Tišljar, Sonja Tomac, Vojko Tomašić, Rozalija Travica, Predrag Vrabec, Mirjana Žerjav, Nevenka Žigić.

15 The film was written, directed and produced by Borut Šeparović. 


\section{Conclusion}

Despite the different reasons, means and ways of confirming, reaching or testing performative unity, the analysed performances share specific characteristics. Firstly, the perception of community in all of the examples (and even some creative processes) is extensive, not limited to the hermetic group of authors but open to those conventionally perceived as recipients. The invitation to participate varies in the level of its directness. It occasionally leads to the immediate establishment of the "autopoietic feedback loop" (Fischer-Lichte 38-74) while at other times inspires potential future project participants. However, it always remains an invitation, although sometimes issued with no "theatrical" alternative. I still remember an elderly visitor of Explicit Contents who refused to follow actors-guides at the beginning of the show only to be leftalone in the empty auditorium of the Zagreb Youth Theatre where she could ponder her dismissal of the group and, I assume involuntarily, of the performance in general. Accordingly, regardless of the emphasised bodily presence, physical invasiveness is steadily avoided. If any "aggression" towards the audience appears, it is in a familiar and mostly acceptable form, for example, intellectual provocation or loud music. Somatic experience is enriched with the mental engagement of the spectator (who is, respectively, in different shows, challenged on both the thematic and formal levels) and their emotional involvement. In the attempt to achieve the latter, the authors can again rely on the content (for example, the documentary material of the performance) as well as the creative methodology (for example, the assumption about the increased personal investment and personal risk of the performer-co-author in the devising process). In both cases, it results in the additional responsibility on the part of the spectator who is reminded to respect the story or the effort and encouraged to respond in kind; for example, as Una Bauer reminds us, the audience members of 55+ - Years Are (Not) Important are burdened with a "guilt trip" if they leave and once again deprive the ordinarily voiceless performers of their voices (2012). What the artists aim for is, however, a short, total joint experience that would not only result in the temporary aesthetic community defined by theatrical conventions but potentially remain as a pledge for future recognition, connection or even closeness between those who shared it. To quote Petković Liker: "That sharp cut which happens in the classical theatre when you see, clap and leave is sometimes good and needed but for me, wasn't correct. This, somehow, doesn't end." (Petković Liker quoted in Kačić Rogošić) 
Bauer, Una. "Nevolje s reprezentacijom," Kulturpunkt, 25 Sep. 2012, www.kulturpunkt. $\mathrm{hr} /$ content/nevolje-s-reprezentacijom. Accessed 30 Jun. 2020.

Bauman, Zygmunt. Community. Seeking Safety in an Insecure World. Polity, 2001.

"Četveroruka manifestno. Problem izvedbenog razmišljanja." cetveroruka.hr/ manifestno/. Accessed 19 Jun. 2020.

Fischer-Lichte, Erika. The Transformative Power of Performance: A New Aesthetics. Routledge, 2008.

Ivšić, Radovan, Dalibor Foretić. “O Družini.” Družina mladih. Čudesna teatarska igra, edited by Seadeta Midžić, and Nada Bezić, ArTresor, Hrvatski glazbeni zavod, 2017, pp. 155-157.

Kačić Rogošić, Višnja. “Conversation with Marina Petković Liker.” 10 Jun. 2020. unpublished.

Kugla glumište. "Što je Kugla?" Gordogan: časopis za književnost i sva kulturna pitanja, vol. 1, no. 1, 1979, p. 79.

Lukić, Darko. Uvod u primijenjeno kazalište. Čije je kazalište?. Leykam international, 2016.

Malec, Ivo, Seadeta Midžić. "Radovan je u svemu bio spiritus movens. Razgovor u povodu smrti Radovana Ivšića”. Družina mladih. Čudesna teatarska igra, edited by Seadeta Midžić and Nada Bezić, ArTresor, Hrvatski glazbeni zavod, 2017, pp. 158166.

Marjanić, Suzana, Anica Vlašić-Anić. "Narušavanje teatra kao kocke. Razgovor sa Zlatkom Burićem Kićom”. Zarez. Dvotjednik za društvena i kulturna zbivanja, no. 211, 2007, pp. 48-49.

Mor, Ivan. "Kugla govor". K. Časopis studenata komparativne književnosti, no. 4-5, 1980, pp. 76-91.

Shadow Casters. [R]evolution Master Class. Programme, 2010.

—. Explicit Contents. Promotional material, 2010.

Šeparović, Borut. "Proutnapad. Odabrani fragmenti teksta o izvedbenom aktivizmu". Kazalište. Časopis za kazališnu umjetnost. vol. 14, no. 47-48, 2011, pp. 66-77.

"Udaljenosti - fokusiranje". cetveroruka.hr/2017/12/01/udaljenost-fokusiranjeposustajanje/. Accessed 22 Jun. 2020.

"Vremeplov". 55plus.montazstroj.hr/?cat=3. Accessed 30 Jun. 2020. 